\title{
A Diagnostic Guide for Volutella Blight Affecting Buxaceae
}

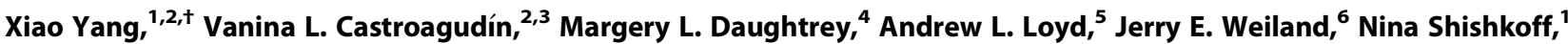 \\ Fulya Baysal-Gurel, ${ }^{7}$ Luisa Santamaria, ${ }^{8}$ Catalina Salgado-Salazar, ${ }^{3}$ James A. LaMondia, ${ }^{9}$ Jo Anne Crouch, $^{3}$ and Douglas G. Luster ${ }^{1,+}$ \\ ${ }^{1}$ United States Department of Agriculture (USDA), Agricultural Research Service (ARS), Foreign Disease-Weed Science Research Unit, Fort \\ Detrick, MD \\ 2 Oak Ridge Institute for Science and Education, ARS Research Participation Program, Oak Ridge, TN \\ ${ }^{3}$ USDA, ARS, Mycology and Nematology Genetic Diversity and Biology Laboratory, Beltsville, MD \\ ${ }^{4}$ School of Integrative Plant Science, College of Agriculture and Life Sciences, Cornell University, Ithaca, NY \\ ${ }^{5}$ Bartlett Tree Research Laboratories, Charlotte, NC \\ ${ }^{6}$ USDA, ARS, Horticultural Crops Research Laboratory, Corvallis, OR \\ ${ }^{7}$ Department of Agricultural and Environmental Sciences, Otis L. Floyd Nursery Research Center, Tennessee State University, McMinnville, TN \\ ${ }^{8}$ North Willamette Research and Extension Center, Oregon State University, Aurora, OR \\ ${ }^{9}$ Connecticut Agricultural Experiment Station, Valley Laboratory, Windsor, CT
}

Accepted for publication 12 June 2021.

Keywords: boxwood, pachysandra, sarcococca, sweet box, Pseudonectria buxi, Pseudonectria foliicola, Coccinonectria pachysandricola

\section{Pathogens}

Volutella blight affecting plants in the Buxaceae family is primarily caused by three distinct fungal species: Coccinonectria pachysandricola (B.O. Dodge) L. Lombard \& Crous, Pseudonectria buxi (DC.) Seifert, Gräfenhan \& Schroers, and Pseudonectria foliicola L. Lombard \& Crous. C. pachysandricola causes Volutella blight on Pachysandra spp. (pachysandra) and Sarcococca spp. (sarcococca; sweet box), whereas $P$. buxi and $P$. foliicola cause Volutella blight primarily on Buxus spp. (boxwood) (Castroagudín et al. 2021; Dodge 1944a, b, c; Lombard et al. 2015; Salgado-Salazar et al. 2019).

Volutella pachysandrae W. G. Hutch. was reported causing leaf blight of Pachysandra terminalis (Hutchinson 1929). Hutchinson (1929) described it as a weak pathogen of Pachysandra terminalis that is also capable of colonizing dead leaves of Buxus sempervirens. Several authors noted the morphological distinction between $C$. pachysandricola and $V$. pachysandrae: namely, that $V$. pachysandrae produces conidia 2 to $6 \mu \mathrm{m}$ long, versus the conidia of $C$. pachysandricola that measure 14 to $20 \mu \mathrm{m}$ in length (Dodge 1944b; Pirone 1942; Samuels

${ }^{\dagger}$ Corresponding authors: X. Yang; xiao.yang@usda.gov and D. G. Luster; doug. luster@usda.gov

Mention of trade names or commercial products in this publication is solely for the purpose of providing specific information and does not imply recommendation or endorsement by the USDA. USDA is an equal opportunity provider and employer.

Funding: This work was supported by the USDA-Agricultural Research Service appropriated projects 8044-22000-046-00-D, 8042-22000-298-00-D, 2072-22000-04300-D, and 0500-00059-001-00-D, the USDA-Animal and Plant Health Inspection Service Farm Bill 10007 program, and the USDA-National Institute of Food and Agriculture Hatch project 1017185. The appointments of X. Yang and V. L. Castroagudín to the ARS Research Participation Program are administered by the Oak Ridge Institute for Science and Education (ORISE) through an interagency agreement between the U.S. Department of Energy (DOE) and the USDA. ORISE is managed by Oak Ridge Associated Universities under DOE contract number DE579AC05-06OR23100.

The author(s) declare no conflict of interest.

This article is in the public domain and not copyrightable. It may be freely reprinted with customary crediting of the source. The American Phytopathological Society, 2021.
1977). However, to the best of our knowledge V. pachysandrae has not been reported in the United States since the 1970s (Farr and Rossman 2020), and there is no evidence that the fungus has been associated with appreciable disease outbreaks since its original description in the early part of the 20th century (Dodge 1944b; Hutchinson 1929; Pirone 1942). Due to the limited information regarding the pathogen following its original description, the lack of a type specimen, and the absence of molecular validation of its species status and generic placement, $V$. pachysandrae is not discussed further in this guide.

In the past, two of the three primary species responsible for Volutella blight, $C$. pachysandricola and $P$. buxi, were known by different names (synonyms). C. pachysandricola was previously known as Volutella pachysandricola. $P$. buxi has gone by 25 different names since its original discovery in 1815, of which readers will be most familiar with the old name Volutella buxi. Although these fungi are now designated by the names of their sexual reproductive stage (Gräfenhan et al. 2011; Lombard et al. 2015), it is their old names for the asexual stage that gave rise to the use of Volutella blight as the common disease name.

\section{Taxonomy}

Classification. Fungi causing Volutella blight affecting Buxaceae, namely $C$. pachysandricola, $P$. buxi, and $P$. foliicola, belong to the kingdom Fungi, subkingdom Dikarya, phylum Ascomycota, subphylum Pezizomycotina, class Sordariomycetes, subclass Hypocreomycetidae, order Hypocreales, and family Nectriaceae.

Electronic resources. The current taxonomic status of C. pachysandricola, P. buxi, P. foliicola, and V. pachysandrae can be retrieved from the United States National Fungus Collections Fungal Databases at https://nt.ars-grin.gov/fungaldatabases/ (Farr and Rossman 2020).

\section{Symptoms and Signs}

Volutella blight of boxwood. Although the symptoms of Volutella blight have led some to refer to the disease as a leaf blight and/or twig dieback, the disease is more properly categorized as a canker disease. This is because the visually striking canopy symptoms 

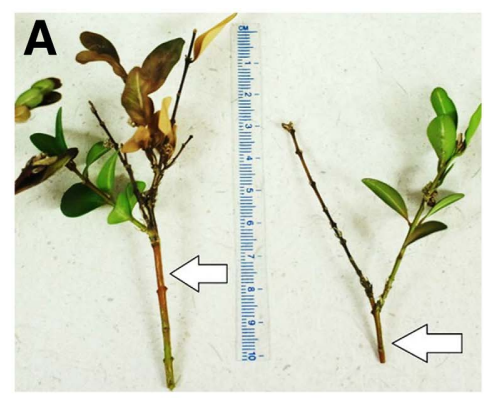

\section{D}
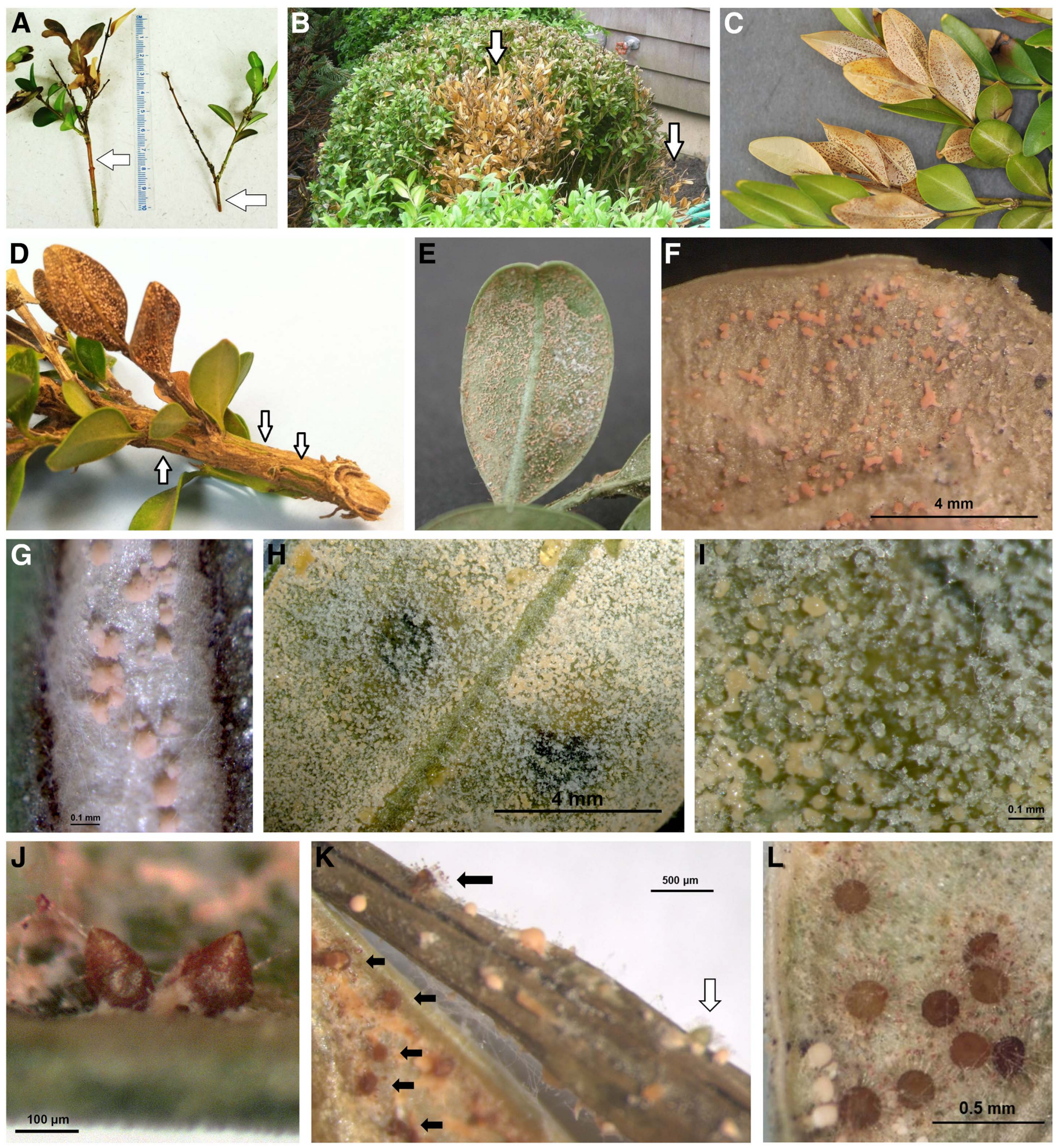

IGURE 1

Symptoms and signs of Volutella blight on boxwood. A, Darkly discolored canker on lower branches (arrows) and subsequent development of leaf and twig blight. B, "Straw-yellow" discolored canopy sections (arrows) of a diseased plant at a landscape site. C, Foliage weakened by Volutella canker and then colonized by black pycnidia of a secondary invader, Neofusicoccum buxi. D, Split and loosened bark (arrows) at the base of a branch supporting blighted foliage. E to G, Pinkish-roseate or coral sporodochia of Pseudonectria buxi on abaxial surface. $\mathbf{H}$ and $\mathbf{I}$, Pink to salmon-colored slimy masses of conidia on sporodochia of Pseudonectria foliicola on abaxial surfaces of infected leaves. J, Two orangey-brown perithecia of $P$. buxi. K, Orange to orangey-brown perithecia (black arrows) and a greenish perithecia (white arrow) of $P$. buxi. L, Nine perithecia of $P$. buxi range in color from grayish yellow green to straw-colored to orangey-brown. Panel $C$ courtesy of Lorraine Graney (Bartlett Tree Experts Company). 
of affected plants are typically the outcome of canker-induced girdling. Cankers are most often located lower down on the same branch as symptomatic leaves (Fig. 1A) (Sinclair et al. 1987; White 1931).

$P$. buxi and $P$. foliicola act as primary invaders of wounded stem tissues (Rivera et al. 2018; Shi and Hsiang 2014b). On mature boxwood, the result is often discoloration of one or more large sections of the canopy (Fig. 1B). This discoloration is often described as "yellowing", but terms such as "straw-yellow" and "tan" are more descriptive of the dull foliage coloration that occurs as the foliage dries out due to girdling caused by supportive branch cankers (Dodge 1944a; Shi and Hsiang 2014b). Macrophoma leaf spot disease caused by the secondary colonizer Neofusicoccum buxi (formerly known as Macrophoma candollei or Dothiorella candollei) commonly occurs on weakened or dead boxwood foliage. Although the formation of black pycnidia of N. buxi (Fig. 1C) (Hansen 2009; White 1931) is sometimes considered as an indication that boxwood foliage is weakened or killed by Pseudonectria spp., particular attention should be paid to not confuse signs and symptoms of Volutella blight with those of Macrophoma leaf spot.

In addition to the presence of cankers, the base of boxwood branches supporting necrotic foliage often contains sections of loosened bark over darkly discolored wood (Fig. 1D) (White 1931). However, it is important to note that split and loosened bark may also be an indication of freeze injury rather than a symptom of Volutella blight (Hansen 2009; Malinoski et al. 2020). Freeze injury is innately harmful and creates wounds that predispose boxwood to infection by Pseudonectria spp.

Because branch cankers of Volutella blight often occur following wounding caused by snow load or winter freezing injury, disease symptoms often start to appear in spring. When first- and secondyear shoots are affected by Volutella blight (in concert with frost injury, for example), short lengths of stem tissue are affected, and dark, brown to black discoloration or streaking may be seen on the affected shoots (Fig. 1A) (Hansen 2009; Shi and Hsiang 2014b). Under humid conditions, Pseudonectria spp. sporulate conspicuously on host tissue, forming sporodochia on abaxial leaf surfaces that are initially whitish and then become pinkish-roseate, salmon-, or coral-colored (Fig. 1E to I) (Dodge 1944a, c; Shi and Hsiang 2014b). Perithecia, like sporodochia, are produced from stomata, and they range in color from grayish yellow green to straw-colored to orangey-brown (Fig. 1J to L) (Rossman et al. 1993).

Only wounded leaves of Buxus are susceptible to infection by Pseudonectria spp. (Shi and Hsiang 2014b). Pathogen invasion of susceptible host tissue is quick when cut leaves are inoculated experimentally: sporulation appears only 3 days after infection (Shi and Hsiang 2014b). Infected leaves become discolored and sometimes abscise. Leaf infection may be facilitated by wounds made by boxwood leafminer or by shearing, a practice that is often carried out multiple times per year on highly maintained boxwood.

Information on possible differences in symptoms on different boxwood species other than B. sempervirens is limited. A report from China describes leaf spots on B. bodinieri with white centers and bronze boundaries (Wang et al. 2017), whereas such an appearance has not been noted on other species, such as $B$. sempervirens (American boxwood) and its hybrids and B. sinica var. insularis (Korean boxwood) (Shi and Hsiang 2014b).

Volutella blight can be readily distinguished from the boxwood blight disease caused by Calonectria spp. (Castroagudín et al. 2020) based on symptoms (Fig. 2). Because of the extent of girdling and cankers associated with Volutella blight, the overall pattern of injury is also markedly different from that of boxwood blight. With Volutella blight, large sections of the affected foliage, often a foot or more in diameter on larger shrubs, are discolored from the stem-girdling effect of cankers on major branches, whereas other parts of the plant may appear green and healthy (Fig. 1B). Damage due to boxwood blight, on the other hand, is primarily due to direct leaf and stem invasion by the causal pathogens, giving rise to many scattered areas of leaf and stem infection along the tops or sides of hedges or free-standing shrubs (Castroagudín et al. 2020). Another key symptomatological difference between Volutella blight and boxwood blight is defoliation: in the case of Volutella blight, affected leaves are typically retained on the branch for some time, whereas in the case of boxwood blight, defoliation usually occurs rapidly (Castroagudín et al. 2020).

Although the dieback symptoms of Volutella blight may resemble those of another boxwood disease, boxwood dieback (or boxwood anthracnose) caused by Colletotrichum theobromicola (Singh and Doyle 2017; Singh et al. 2015), several diagnostic traits can be used to differentiate these two diseases. First, the stems and branches affected by Volutella blight do not show the bright black discoloration under the bark typical of boxwood dieback (Singh and Doyle 2017). Second, Pseudonectria spp. often produce abundant sporodochia on the adaxial side of infected leaves, whereas those of the boxwood dieback fungus are mostly localized upon stems and twigs. Third, Pseudonectria spp. and Colletotrichum theobromicola are different in setae color. A comparison chart including diagnostic traits of these three major fungal diseases of Buxus spp., namely, Volutella blight, boxwood blight, and boxwood dieback, is provided in Figure 2.

Volutella blight of pachysandra. The symptoms of Volutella blight on pachysandra caused by $C$. pachysandricola are a familiar sight in many diagnostic laboratories. Leaf lesions are initially circular (Fig. 3A) and then grow to form large, irregular blotches, light to dark brown in color, sometimes with a darker brown margin or yellow halo (Fig. 3B and C). A zonate pattern is often seen in the lesions (Fig. 3A to C), which may continue to expand until leaves and shoots are blighted (Fig. 3D and E) (Bai et al. 2012; Douglas 2008; Sinclair et al. 1987). Cankers initially appear water-soaked and darken from greenish brown (Fig. 3D) to darker brown or black (Fig. $3 \mathrm{E}$ ), eventually expanding to such an extent that they may girdle stems and stolons (Fig. 3E and F) (Bai et al. 2012; Douglas 2008; Šafránková 2007; Sinclair et al. 1987). Circular salmon-colored (brighter pink-orange when moist) sporodochia, sometimes bearing hyaline setae, form on recently killed stems (Fig. 3D and E) and the abaxial leaf surface (Fig. 3G). During spring and summer months, orange to carmine-red perithecia with short, thick-walled setae form on diseased tissue from reddish stromatic masses (Fig. 3H) (Dodge 1944b; Douglas 2008; Han et al. 2012; Šafránková 2007; Sinclair et al. 1987). The gardener's greatest concern, however, is stem and stolon infections (Fig. 3D to F). These often occur in late winter and result in thinning or death of large groundcover plantings of pachysandra (Fig. 3I) (Pirone 1942). Severity of symptoms in pachysandra from this facultative parasite is correlated with plant stress (Hudler et al. 1990). Wounding facilitates but is not required for infection (Salgado-Salazar et al. 2019).

Volutella blight of sarcococca. $C$. pachysandricola causes Volutella leaf spots on Sarcococca hookeriana and S. hookeriana var. humilis (Castroagudín et al. 2021; Salgado-Salazar et al. 2019). Infection on $S$. hookeriana is increased by wounding (Castroagudín et al. 2021; Salgado-Salazar et al. 2019). Brownspotted leaves and stem cankers were initially noted on sarcococca plants growing near pachysandra (Fig. 4A to C) (Salgado-Salazar et al. 2019). Leaf lesions exhibit a zonate banding pattern (Fig. 4A and B), similar to those seen on pachysandra leaves infected by 
C. pachysandricola (Fig. 4A). Lesions are irregularly shaped and often start at the leaf tip (Fig. 4). In some cases, infected leaves are chlorotic and become completely blighted (Fig. 4B to D).

\section{Host Range}

C. pachysandricola causes leaf blight on Pachysandra spp., $S$. hookeriana, and S. hookeriana var. humilis, but the fungus has not been reported as a pathogen of Buxus spp. (Castroagudín et al. 2021; Dodge 1944b; Lombard et al. 2015; Salgado-Salazar et al. 2019). North American native Pachysandra procumbens (Allegheny pachysandra) is reported to be less susceptible to this pathogen than the Asian native Pachysandra terminalis (Japanese spurge or Japanese pachysandra) (Douglas 2008). All cultivars of Pachysandra terminalis are considered susceptible to $C$. pachysandricola (Douglas 2008); however, explicit reports of infection are only available for the cultivars 'Green Carpet' and 'Variegata' (Šafránková 2007).

$P$. buxi is reliably reported only from hosts in the genus Buxus (Farr and Rossman 2020; Salgado-Salazar et al. 2019). Susceptible hosts of P. buxi include but are not limited to B. microphylla, B. microphylla var. japonica, B. sempervirens cultivars 'Arborescens' and 'Suffruticosa', and B. sinica var. insularis (Bezerra 1963; Farr and Rossman 2020; Rivera et al. 2018). Infection was also noted on hybrid cultivars. For example, $P$. buxi was recovered from cultivar 'Glencoe' ('Chicagoland Green') in British Columbia, Canada (Shi and Hsiang 2014b). Unusually severe and widespread infections ( $>50 \%$ loss) during nursery propagation in Ontario, Canada, were reported on plants belonging to the Sheridan hybrids (B. sinica var. insularis $\times$ B. sempervirens) (Shi and Hsiang 2014b). Specifically, cultivars 'Green Gem', 'Green Velvet', 'Green Mound', 'Green Mountain', and 'Pincushion' were reported to show different levels of susceptibility to P. buxi under experimental conditions (Shi and Hsiang 2014b). Shi and Hsiang (2014b) reported that cultivar Pincushion with low susceptibility to insects also exhibited low susceptibility to $P$. buxi inoculation.

$P$. foliicola was first described as a boxwood pathogen, but it has been occasionally recovered from sarcococca (Lombard et al. 2015; Salgado-Salazar et al. 2019). The ability of $P$. buxi and $P$. foliicola to colonize plants outside the Buxaceae as endophytes is not known, but they are so frequently isolated from surfacedsterilized boxwood tissues in diagnostic laboratories that they appear to be endophytes or latent pathogens of Buxus spp.

$C$. pachysandricola, $P$. buxi, and $P$. foliicola are shown to exhibit variability among isolates in pathogenicity and in their dependence on the presence of wounds; however, differences in aggressiveness are poorly understood (Castroagudín et al. 2021; Dodge 1944b; Hudler et al. 1990; Salgado-Salazar et al. 2019). As of yet, no extensive, methodical research has been conducted on the susceptibility of different species and varieties of Buxus, Pachysandra, and Sarcococca and their companion plants, such as begonia, geranium,

\begin{tabular}{|c|c|c|c|c|}
\hline \multicolumn{2}{|l|}{ Diagnostic traits } & \multirow{2}{*}{$\begin{array}{l}\text { Volutella blight } \\
\text { Relatively large sections of } \\
\text { the canopy due to infection } \\
\text { on supporting branch } \\
\text { bases }\end{array}$} & \multirow{2}{*}{$\begin{array}{l}\text { Boxwood blight } \\
\text { Starts with scattered, } \\
\text { relatively small areas due to } \\
\text { leaf infection, then spreads } \\
\text { to the entire foliage }\end{array}$} & \multirow{2}{*}{$\begin{array}{l}\text { Boxwood dieback }^{\mathbf{b}} \\
\text { Relatively large sections of } \\
\text { the canopy due to infection } \\
\text { on supporting branch bases } \\
\text { and individual twigs }\end{array}$} \\
\hline Symptoms on boxwood & $\begin{array}{l}\text { Blighted canopy } \\
\text { pattern }\end{array}$ & & & \\
\hline & Leaf spots & None & $\begin{array}{l}\text { Extensive at the early stage } \\
\text { following infection of } \\
\text { Calonectria henricotiae and } \\
\text { Ca. pseudonaviculata }\end{array}$ & $\begin{array}{l}\text { Colletotrichum } \\
\text { theobromicola occasionally } \\
\text { causes leaf spots (R. Singh, } \\
\text { personal communication). }\end{array}$ \\
\hline & Defoliation & $\begin{array}{l}\text { Minimum, blighted leaves } \\
\text { tend to remain attached }\end{array}$ & $\begin{array}{l}\text { Rapid and extensive, occurs } \\
\text { within days after infection } \\
\text { under favorable conditions }\end{array}$ & $\begin{array}{l}\text { Minimum, tan-colored } \\
\text { leaves tend to remain } \\
\text { attached }\end{array}$ \\
\hline & Stem cankers & $\begin{array}{l}\text { Brown to black streaks, } \\
\text { girdling, but can be vertical } \\
\text { when associated with } \\
\text { loosened bark caused by } \\
\text { winter damage; some } \\
\text { discoloration of wood } \\
\text { associated with loosened } \\
\text { and peeling bark }\end{array}$ & $\begin{array}{l}\text { Extensive vertical black } \\
\text { streaks on susceptible hosts; } \\
\text { discoloration is shallow, } \\
\text { limited to the bark, rarely } \\
\text { extends to the xylem. }\end{array}$ & $\begin{array}{l}\text { Stems with dieback show } \\
\text { bright black discoloration } \\
\text { under the bark; } \\
\text { discoloration can extend } \\
\text { into the xylem and pith. }\end{array}$ \\
\hline \multirow[t]{5}{*}{ Pathogen morphology } & Color of sporodochia & $\begin{array}{l}\text { Initially white, quickly } \\
\text { turning pinkish-roseate, } \\
\text { salmon-, or coral-colored }\end{array}$ & White & Salmon-colored \\
\hline & $\begin{array}{l}\text { Location of } \\
\text { sporodochia }\end{array}$ & $\begin{array}{l}\text { Abundant on the adaxial } \\
\text { surface of leaves; } \\
\text { sometimes observed on } \\
\text { the stems }\end{array}$ & $\begin{array}{l}\text { Abundant on the leaf adaxial } \\
\text { surface and stems, } \\
\text { associated with leaf spots } \\
\text { and stem cankers }\end{array}$ & $\begin{array}{l}\text { Sometimes developed on } \\
\text { infected stems and twigs }\end{array}$ \\
\hline & Conidial shape & $\begin{array}{l}\text { Fusoid (Pseudonectria } \\
\text { buxi); Fusiform to } \\
\text { ellipsoidal }(P \text {. foliicola) }\end{array}$ & $\begin{array}{l}\text { Two-celled, elongated } \\
\text { cylindrical }\end{array}$ & $\begin{array}{l}\text { Single-celled, short } \\
\text { cylindrical }\end{array}$ \\
\hline & Setae color & Hyaline to whitish & Not observed & Black \\
\hline & Perithecia & $\begin{array}{l}\text { Dark brown, straw-colored, } \\
\text { or grayish yellow green, } \\
\text { pear shaped, appear at } \\
\text { the end of the season }\end{array}$ & $\begin{array}{l}\text { Not observed on host tissue; } \\
\text { Rounded, orange to red } \\
\text { perithecia produced by } \\
\text { crosses of two boxwood } \\
\text { blight fungi on carrot agar }\end{array}$ & $\begin{array}{l}\text { Not observed on host tissue } \\
\text { or artificial media }\end{array}$ \\
\hline
\end{tabular}

a Additional information including diagnostic images of boxwood blight can be found in Castroagudín et al. (2020).

${ }^{\mathrm{b}}$ Additional information including diagnostic images of boxwood dieback can be found in Singh and Doyle (2017).

\section{FIGURE 2}

Comparative diagnostic characters of three major fungal diseases on Buxus spp., including Volutella blight caused by Pseudonectria buxi and $P$. foliicola, boxwood blight caused by Calonectria henricotiae and Calonectria pseudonaviculata, and boxwood dieback (or boxwood anthracnose) caused by Colletotrichum theobromicola. 
iris, liriope, and thyme, to Volutella blight. Several Pseudonectria spp. have been described as endophytes, saprophytes, and secondary invaders (Collado et al. 1999; Lombard et al. 2015; Salgado-Salazar et al. 2019). It is not unusual to recover the Volutella blight pathogens from diagnostic clinic samples of boxwood, pachysandra, and sarcococca that have been killed or weakened by other aggressive pathogens, such as the boxwood blight fungi (Castroagudín et al. 2020, 2021) and Phytophthora spp. (Erwin and Ribeiro 1996; Hansen 2009; Reeser et al. 2015), or by environmental stresses, particularly winter injury.

\section{Geographic Distribution}

C. pachysandricola has been documented from reports and herbarium specimens (https://www.mycoportal.org/) from China, the Czech Republic, England, Germany, Japan, Korea, the Netherlands, and the United Kingdom (Bai et al. 2012; Cannon et al. 1985; Han et al. 2012; Kobayashi 2007; Lombard et al. 2015; Šafránková 2005). In North America, it has been formally documented through reports and herbarium specimens (https://www.mycoportal.org/) in the U.S. states of Connecticut, Delaware, Florida, Kansas, Maryland, New Jersey, New York, North Carolina, Ohio, Pennsylvania, Virginia, and West Virginia, and the District of Columbia (Anonymous 1960; Gräfenhan et al. 2011; Rogerson 1953; Salgado-Salazar et al. 2019).

Following its original description when recovered from dead and dying leaves of Buxus sp. in France in 1815, P. buxi has been documented from at least 25 countries. In Europe and Asia, reports and herbarium specimens (https://www.mycoportal.org/) show that $P$. buxi colonizes boxwood in Armenia, Austria, Belgium, Bulgaria, China, the Czech Republic, Denmark, England, France, Germany, Greece, Ireland, Italy, the Netherlands, Norway, Poland, Portugal, Russia, Scotland, Spain, Slovakia, Sweden, Turkey, and Ukraine (Akıllı Şimşek et al. 2019; Bobev 2009; Cannon et al. 1985;
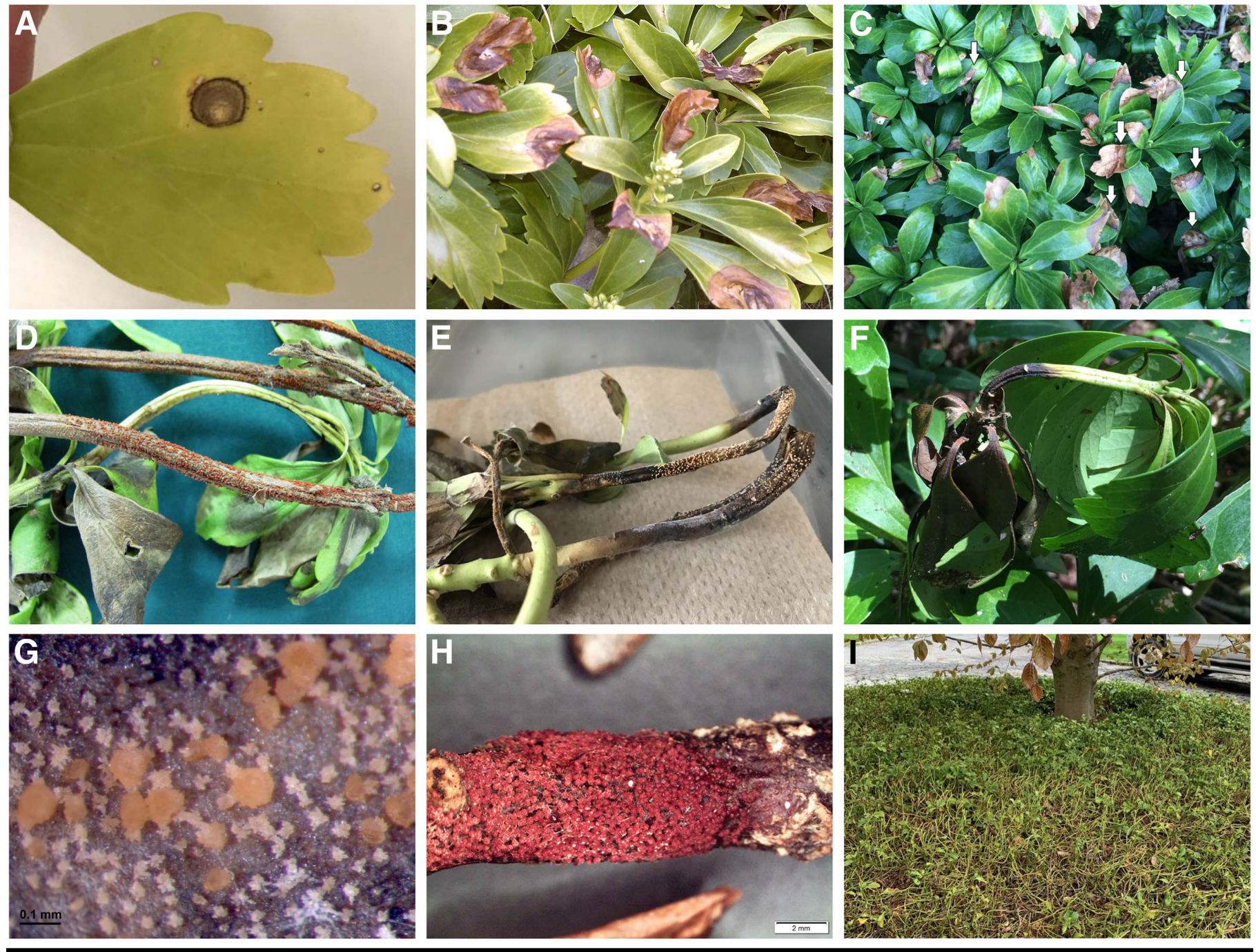

FIGURE 3

Symptoms and signs of Volutella blight caused by Coccinonectria pachysandricola on pachysandra. A, A circular leaf lesion at the early stage of infection. B and C, Circular and irregular lesions on leaves. Note the characteristic zonate pattern of the lesions (arrows). D, Greenish brown cankers, salmon-colored sporodochia, and orange perithecia on infected stems. E, Circular salmon-colored sporodochia on blighted leaves and shoots and girdling stems and stolons with dark brown to black cankers. F, Girdling on an infected pachysandra stem. G, Salmon-colored sporodochia and orange perithecia on the underside of an infected leaf. $\mathbf{H}$, Orange to carmine-red perithecia on a diseased stem. I, Volutella blight observed during winter at a landscape site, showing characteristic thinning of the stand of pachysandra. Panels B, D, and H courtesy of Chad A. Vrany, Lorraine Graney, and Meg McConnell (Bartlett Tree Experts Company), respectively. Panel I courtesy of Vincent A. Simeone (Planting Fields Arboretum). 
de Sousa Dias et al. 1987; Eriksson 1992; Farr and Rossman 2020; Garibaldi et al. 2016; Lombard et al. 2015; Mulenko et al. 2008; Munk 1957; Pantidou 1973; Salgado-Salazar et al. 2019; Shi and Hsiang 2014a; Simonyan 1981; Spetik et al. 2019; Unamuno 1941; Wang et al. 2017). In South America, P. buxi has been reported in Brazil (Andrade et al. 2017). In North America, formal reports and specimens of $P$. buxi come from Canada (Shi and Hsiang 2014b) and from sixteen U.S. states: Alabama, California, Connecticut, Florida, Illinois, Kansas, Maryland, Mississippi, Ohio, New Jersey, New York, North Carolina, Oregon, Pennsylvania, Rhode Island, and Virginia (Alfieri et al. 1984; Farr and Rossman 2020; French 1989; Grand 1985; Lambe and Wills 1975; Rogerson 1956; Salgado-Salazar et al. 2019).

The recently described species $P$. foliicola has been documented from boxwood in three countries. These reports were made from the Czech Republic, New Zealand, and within North America from six U.S. states, namely, Illinois, Maryland, Massachusetts, North Carolina, Tennessee, and Washington (Baysal-Gurel et al. 2021; Lombard et al. 2015; Salgado-Salazar et al. 2019; Spetik et al. 2020).
Any discussion of the geographic distribution of these two Pseudonectria spp. is not complete without reminding the reader that more than 200 years of taxonomic changes and multiple new names make it difficult to specifically connect disease reports prior to 2015 to either $P$. buxi or $P$. foliicola. Because $P$. foliicola was identified for the first time in 2015, it is possible that many of the pre-2015 morphology-based identifications of $P$. buxi might represent misdiagnosed instances of $P$. foliicola (Lombard et al. 2015).

\section{Pathogen Isolation}

C. pachysandricola, P. buxi, and P. foliicola can be isolated by directly transferring conidia, which are produced on the sporodochia that are usually present on dying leaves and stems (Figs. 1E to I, and 3D, E, and G), to a growth medium. Specifically, transfers can be made from these fruiting bodies by dipping a sterile loop or pick into sterile water, lightly touching a sporodochium with the tool, and then streaking the conidia onto full- or halfstrength potato dextrose agar (PDA) amended with streptomycin
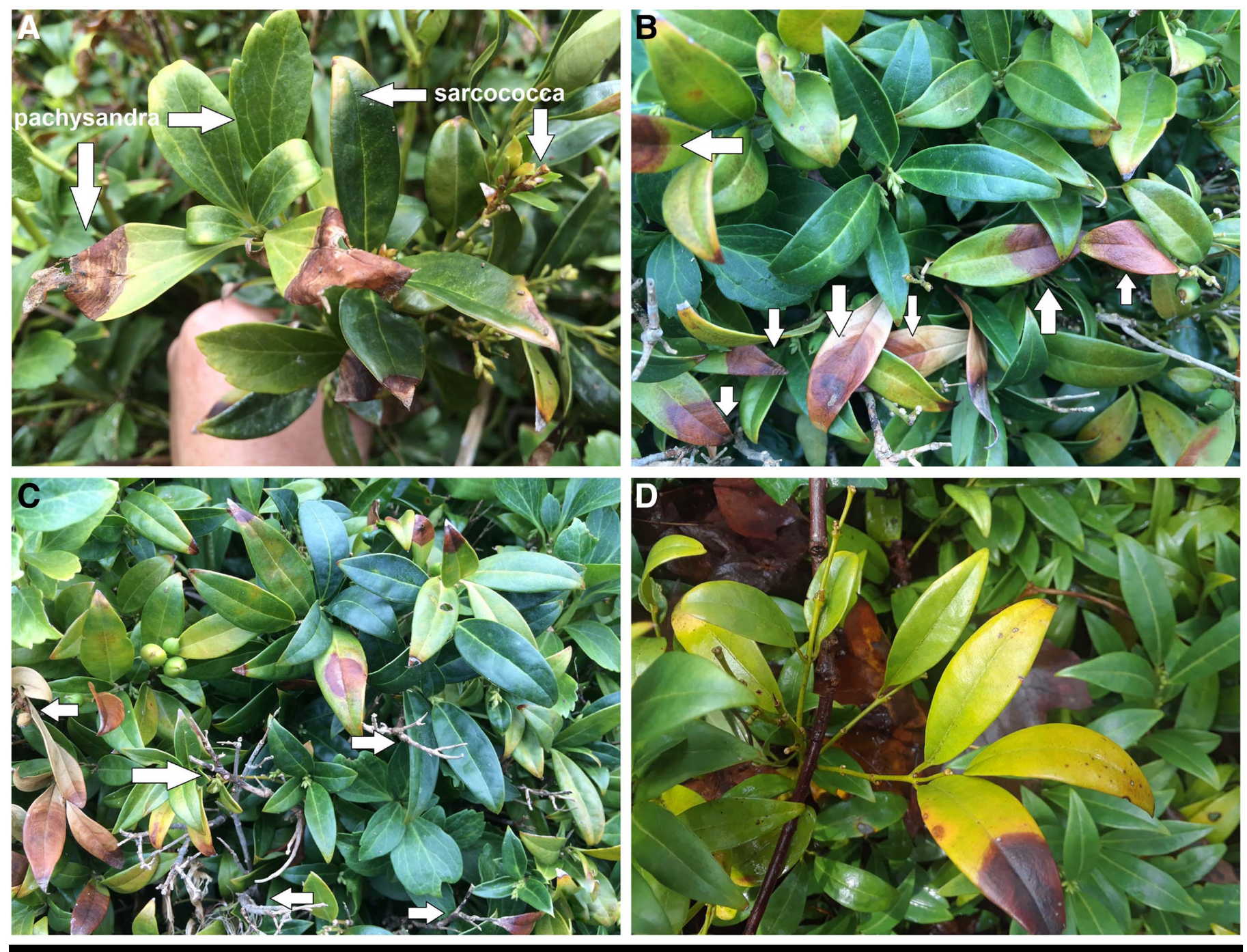

FIGURE 4

Symptoms and signs of Volutella blight on sarcococca. A, Sarcococca (right) infected by Coccinonectria pachysandricola growing near C. pachysandricolainfected pachysandra (left) at the U.S. National Arboretum in Washington D.C. B, Brown and irregular lesions (arrows), elongated in outline on sarcococca leaves. Note the characteristic zonate pattern of the lesions often started at the leaf tip. C, Blighted tips and stem cankers (arrows). D, Leaves turning yellow from the brown spots at the leaf tip. 
(50 to $100 \mathrm{mg} /$ liter) or tetracycline $(100 \mathrm{mg} /$ liter) to inhibit bacterial growth (Castroagudín et al. 2021; Shi and Hsiang 2014b). When sporodochia are absent, their production can be facilitated by incubating infected leaves and stems in a moist chamber at 20 to $25^{\circ} \mathrm{C}$ in the dark or under a 12-h photoperiod (Salgado-Salazar et al. 2019). Surface disinfestation of plant tissues is optional but may help reduce contamination by bacteria and other fungi. Surface sterilization can be performed by placing tissues into $1 \% \mathrm{NaOCl}$ for $30 \mathrm{~s}$ to $1 \mathrm{~min}$, rinsing in $70 \% \mathrm{EtOH}$, and then allowing the leaves to dry briefly in a laminar flow hood before incubating in a moist chamber. White, immature sporodochia develop within 2 to 7 days (Fig. 5A). Once the sporodochia have turned salmon pink color, the conidia are mature enough to be transferred to new plates as described above (Castroagudín et al. 2021; Shi and Hsiang 2014b). Conidia germinate within 1 to 2 days, and at this point single-spore isolates can be transferred to new PDA plates. Cultures develop a salmon pink center with a white edge within a few days after they have been placed at 20 to $25^{\circ} \mathrm{C}$. Care must be taken not to confuse cultures of Coccinonectria and Pseudonectria with those of Fusarium spp. Species of Fusarium commonly inhabit healthy and dying boxwood tissues and, in common with $P$. buxi and $P$. foliicola, may produce visually similar pink sporodochia and colonies. However, mature Fusarium cultures usually develop a magenta pink to red colony center (Fig. 6D), whereas those of Coccinonectria and Pseudonectria spp. are more salmon pink to orange in color (Fig. 6A to C) (Lombard et al. 2015; Salgado-Salazar et al. 2019). Furthermore, Fusarium spp. can be differentiated from the fungi causing Volutella blight based on conidial morphology. Fusarium spp. commonly develop two spore types: (i) microconidia, aseptate or septate, short and ellipsoidal, may potentially be confused with the conidia of Coccinonectria and Pseudonectria spp.; and (ii) macroconidia, septate, with or without a foot cell, long and curved to crescent or sickle-shaped and very distinct from the morphological characters of C. pachysandricola, P. buxi, and P. foliicola, which are detailed in the next section.

\section{Pathogen Identification by Morphology}

P. buxi. Bezerra (1963) examined boxwood tissues infected by $P$. buxi and described light reddish to pink hemispherical sporodochia (Fig. 1E to G) 60 to $110 \mu \mathrm{m}$ in diameter (Fig. 5B), with setae up to $190 \mu \mathrm{m}$ long (Fig. 5A). Rossman et al. (1993) described the sporodochia as nonstromatic, easily detached from substrate, 50 to $240 \mu \mathrm{m}$ in diameter, with red-tipped, hyaline setae 80 to $180 \mu \mathrm{m}$ long. Conidiophores bearing phialides (Fig. 5C) were 45 to $75 \mu \mathrm{m}$ long (Bezerra 1963), or 19 to $43 \mu \mathrm{m}$ long and weakly verticillate (Rossman et al. 1993). Conidia were fusoid, hyaline, smooth, one-celled (Fig. 5D), 8 to $12 \times 2.5$ to $3 \mu \mathrm{m}$ (Bezerra 1963); 4.4 to $5.8 \times 2.1$ to $2.9 \mu \mathrm{m}$ on plants and 2.8 to $8.7 \times 1.9$ to $4.3 \mu \mathrm{m}$ in culture (Rossman et al. 1993); 6 to $9 \times 2$ to $2.5 \mu \mathrm{m}$ on Korean boxwood (Shi and Hsiang 2014a); 8.7 to $14.0 \times 1.9$ to $3.5 \mu \mathrm{m}$ on leaves and 3.6 to $6.5 \times 1.8$ to $3.5 \mu \mathrm{m}$ on PDA (Garibaldi et al. 2016); 3.8 to $8.6 \times 1.9$ to $5.2 \mu \mathrm{m}$ (Wang et al. 2017). When Bezerra (1963) grew $P$. buxi in oatmeal agar, mycelia grew immersed in the agar and produced sporodochia similar to the ones observed on host tissue. Aerial mycelia developed at the margins of older cultures, which contained chlamydospores that were elliptic to globose, one-celled, hyaline, terminal, sometimes intercalary, and 13 to $25 \times 13$ to $22 \mu \mathrm{m}$. Bezerra (1963) reported abundant growth of $P$. buxi both immersed and aerially on PDA, but no sporulation. Rossman et al. (1993) observed $P$. buxi colonies 2.2 to $2.4 \mathrm{~cm}$ in diameter after 5 days on PDA, with sparse, white, aerial mycelia turning pale salmon due to production of sporodochia (Fig. 6A), eventually producing diffuse sporodochia with sparse, redtipped setae.

From diseased leaves, Bezerra (1963) described perithecia as pear shaped, light orange to greenish, setose, 135 to $190 \mu \mathrm{m}$ in diameter, and 180 to $250 \mu \mathrm{m}$ high; hyaline setae were 50 to $110 \mu \mathrm{m}$ long (Fig. $1 \mathrm{~J}$ to L). The unitunicate asci measuring 50 to $70 \times 8$ to $10 \mu \mathrm{m}$ were clavate and contained eight ascospores (Fig. 5E). Ascospores were fusoid, rounded at both ends, hyaline, thinwalled, one-celled, 11 to $17 \mu \mathrm{m}$ long and 3 to $5 \mu \mathrm{m}$ wide, greyish yellow to green (Fig. 5E). Rossman et al. (1993) described perithecia as 190 to $204 \mu \mathrm{m}$ high $\times 168$ to $175 \mu \mathrm{m}$ wide, luteous, straw-colored or with hyaline setae ( 25 to) 56 to $160 \mu \mathrm{m}$ long with finely granular encrustations on the surface (Fig. 1J to L). Asci measured 43 to $52 \times 7.4$ to $11.2 \mu \mathrm{m}$. Ascospores measured 11.7 to 15.7 (to 17.6 ) $\times 3.7$ to 4.3 (to 5 ) $\mu \mathrm{m}$ (Fig. $5 \mathrm{E}$ ).

Cautious interpretation of sexual structures for diagnostic purposes is recommended. In particular, our ability to uniquely connect the sexual structures described for the boxwood-infecting Pseudonectria with either $P$. buxi or P. foliicola is incomplete, and additional research on the topic is needed. In the past, two distinct sexual morphs were described for boxwood-infecting Pseudonectria under the dual-name system of fungal nomenclature: $P$. rousseliana, which is a synonym of $P$. buxi; and $P$. coronata, which is a homotypic synonym of Nectriella coronata (Rossman et al. 1993). Both of these sexual morphs can coexist on a single boxwood leaf, as was documented from the type specimen of P. rousseliana (Rossman et al. 1993). However, studies of the sexual morphs took place several decades before mycologists were aware of the existence of $P$. foliicola, and sexual fruiting bodies were not identified when P. foliicola was described (Bezerra 1963; Lombard et al. 2015; Rossman et al. 1993). The sexual structures detailed above for $P$. buxi are based on descriptions of $P$. rousseliana; for a complete description of $P$. coronata, consult Rossman et al. (1993).

Gräfenhan et al. (2011) correlated perithecial color with Pseudonectria spp., distinct from species belonging to the Volutella sensu stricto clade, noting that Pseudonectria spp. produced green perithecia and Volutella spp. produced red perithecia. While preparing images for this guide, we observed a range of perithecial colors associated with the setose sporodochia of $P$. buxi on boxwood leaves, ranging from orangey-brown to orange to greenish to grayish yellow green to straw colored (Fig. $1 \mathrm{~J}$ to L). It is worth noting that perithecia of additional nectriaceous fungi have also been observed from dying or dead boxwood leaves, including Hyponectria buxi and Sesquicillium buxi (Rossman et al. 1993).

P. foliicola. $P$. foliicola was described as a fungus similar to $P$. buxi but without a known perithecial state, whose sporodochia on plant tissue lacked setae and whose conidia could form both on single conidiophores on plant tissue and multiple conidiophores on sporodochia (Fig. 5F) (Lombard et al. 2015). On diseased leaves, the single conidiophores are often visible first, appearing as a pale pink lawn of erect hyphae with irregularly verticillate spore droplets that persist when sporodochia arise. Conidia are hyaline, aseptate, fusiform to ellipsoidal (Fig. 5G), (5 to) 6.5 to 7.5 (to 8 ) $\times 2$ to $3 \mu \mathrm{m}$ (average $7 \times 3 \mu \mathrm{m}$ ) (Lombard et al. 2015); or $4.5 \pm 0.9 \times 2.9 \pm 0.4 \mu \mathrm{m}$ (Spetik et al. 2020). Lombard et al. (2015) reported fast-growing colonies on malt extract agar (MEA), reaching $90 \mathrm{~mm}$ in 10 days at $24^{\circ} \mathrm{C}$ with hyaline chlamydospores, globose to subglobose, 35 to $60 \mu \mathrm{m}$ in diameter, intercalary in chains or solitary. Spetik et al. (2020) reported colonies on PDA with white aerial mycelia and scattered pink to salmon, slimy masses of conidia on sporodochia at the margins (Fig. 6B). 

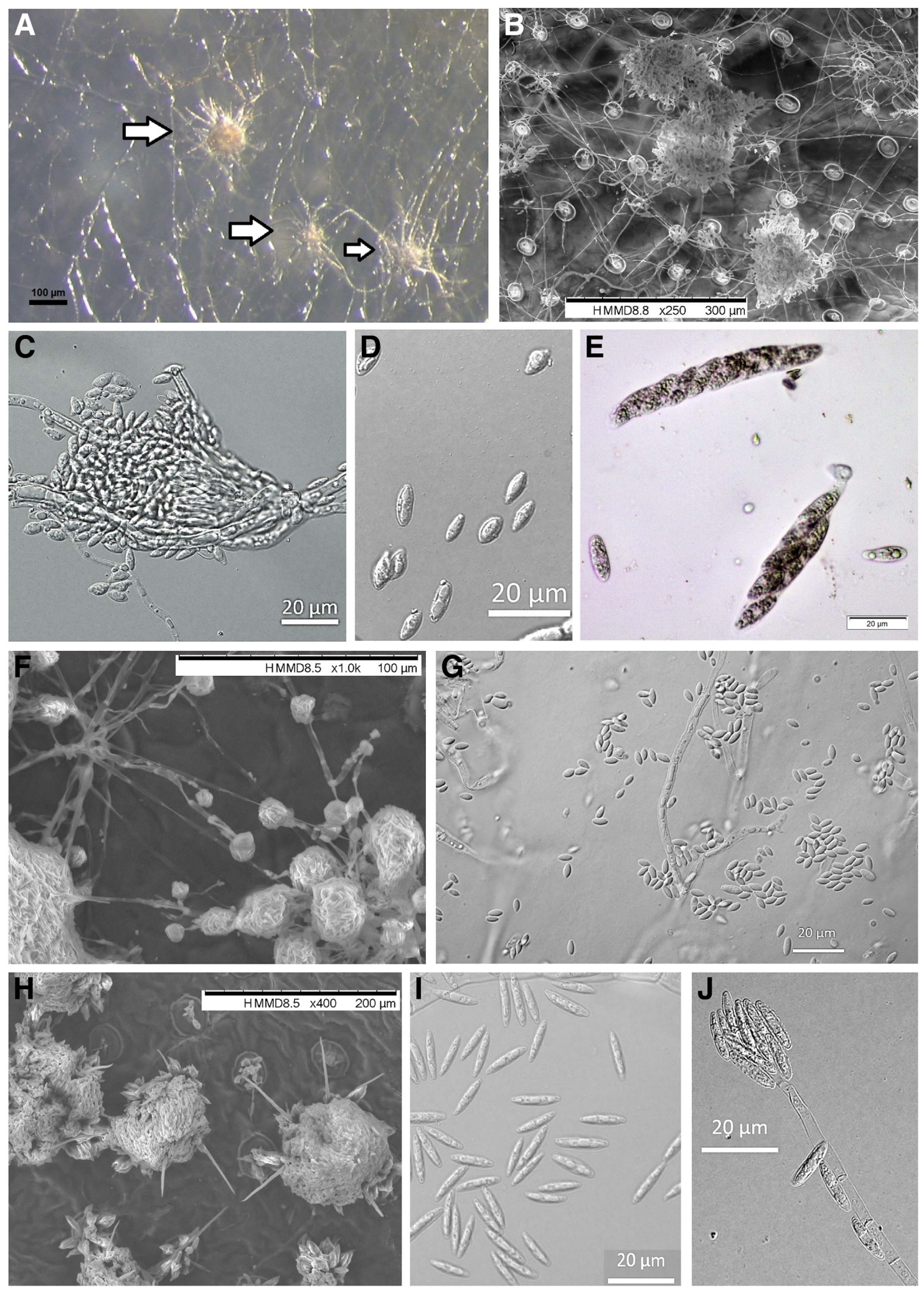

\section{FIGURE 5}

Morphological features of fungi causing Volutella blight on Buxaceae. Pseudonectria buxi: A, white, immature sporodochia bearing hyaline setae (arrows) produced 7 days after being plated on potato dextrose agar; B, hemispherical sporodochia on infected leaf tissue observed under a scanning electron microscope (SEM); $\mathbf{C}$, solitary conidiophore bearing phialides on fasciculate, aerial hyphae; $\mathbf{D}$, aseptate, hyaline, ellipsoid to fusiform, and smooth-walled conidia; and $\mathbf{E}$, unitunicate, clavate asci, each containing eight hyaline fusoid, thin-walled, one-celled ascospores. Pseudonectria foliicola: $\mathbf{F}$, conidia forming both on single conidiophores growing out of a stoma as well as ones forming sporodochia on an infected leaf under SEM; and G, hyaline, aseptate, fusiform to ellipsoidal conidia. Coccinonectria pachysandricola: $\mathbf{H}$, sporodochia with hyaline setae on an infected leaf under SEM; I, ellipsoid, hyaline, and aseptate conidia; and $\mathbf{J}$, a simple verticillate conidiophore with conidia. Panel E courtesy of Lorraine Graney (Bartlett Tree Experts Company). 
Lombard et al. (2015) indicated that $P$. foliicola can be differentiated from $P$. buxi by its simple conidiophores, something not reported for P. buxi (Bezerra 1963; Rossman et al. 1993). Additionally, conidia of P. foliicola (Fig. 5G) are smaller than those of P. buxi (Fig. 5D), which are 8 to $12 \times 2.5$ to $3 \mu \mathrm{m}$ (Bezerra 1963). Also, the sporodochia of $P$. foliicola are not surrounded by setae, whereas formation of setae is a characteristic of P. buxi (Fig. 5A) (Bezerra 1963; Rossman et al. 1993). However, in our own experience, we have not always observed setae from $P$. buxi grown in culture, but these features are regularly observed from natural infections of host tissue by $P$. buxi (C. Salgado-Salazar, personal communication). In general,
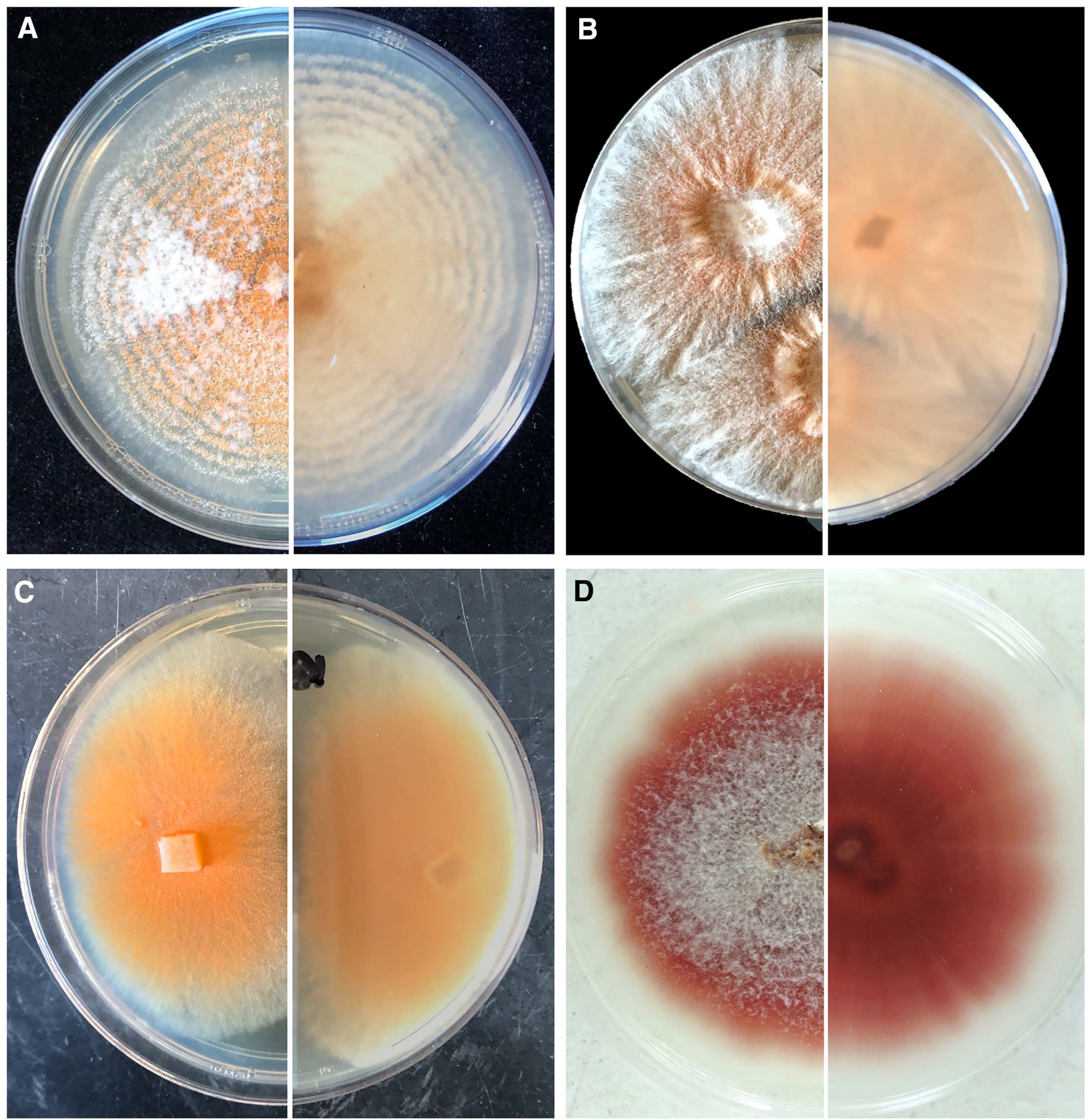

D

FIGURE 6

Colony morphology of A, Pseudonectria buxi; B, Pseudonectria foliicola; C, Coccinonectria pachysandricola; and D, a Fusarium species isolated from boxwood. All cultures were grown in potato dextrose agar at $25^{\circ} \mathrm{C}$ under fluorescent light. The $P$. buxi culture was maintained under a $12-\mathrm{h}$ photoperiod for 16 days, whereas the others were under a $24-\mathrm{h}$ photoperiod for 10 days. 
we have also observed that $P$. foliicola sporulates profusely, whereas $P$. buxi does not sporulate as much, but we do not know how widespread this trait might be across all populations of these two fungal species.

C. pachysandricola. Signs of C. pachysandricola on the plant are mucoid, salmon-colored sporodochia with hyaline or faintly colored setae (Fig. 3D, E, and G). The tapered setae (Fig. 5H) measure 100 to $200 \mu \mathrm{m}$ long (Dodge 1944b) or 60 to $100 \mu \mathrm{m}$ long (Han et al. 2012). A dissecting needle touched to the spore-laden surface of a sporodochium, then touched to a drop of water on a microscope slide, releases spores, which under magnification are aseptate, smooth, hyaline, and ellipsoidal to fusiform (Fig. 5I). Conidial dimensions of $C$. pachysandricola from pachysandra were given by Dodge (1944b) as 14 to $24 \times 2$ to $4 \mu \mathrm{m}$ (more variable in size and shape in culture on PDA); by Rossman et al. (1993) as (6.8 to) 12 to $21 \times 3.1$ to $4.3 \mu \mathrm{m}$; by Han et al. (2012) as 11 to $26 \times$ 2.5 to $4.0 \mu \mathrm{m}$; and from sarcococca by Salgado-Salazar et al. (2019) as 11 to $23 \times 2$ to $5 \mu \mathrm{m}$ (average $15.4 \times 3.1 \mu \mathrm{m}$ ). According to Salgado-Salazar et al. (2019), isolates of $C$. pachysandricola (Fig. 5I) could be readily distinguished from $P$. buxi and $P$. foliicola based on the size of their conidia ( $P$. buxi: 8 to $12 \times 2.5$ to $3 \mu \mathrm{m} ; P$. foliicola: 6.5 to $7.5 \times 2$ to $3 \mu \mathrm{m})$.

Rossman et al. (1993) described colonies of $C$. pachysandricola from pachysandra grown on PDA as $2 \mathrm{~cm}$ in diameter with sparse aerial mycelia near the margins, with solitary conidiophores that are unbranched, irregularly verticillate with monophialidic conidiogenous cells 9.3 to $19 \times 2.5$ to $3.7 \mu \mathrm{m}$ at the base and $1.9 \mu \mathrm{m}$ at the apex (Fig. 5J). Salgado-Salazar et al. (2019) described colonies of isolates from sarcococca as effuse and salmon-white on PDA (Fig. 6C), reaching 26 to $35 \mathrm{~mm}$ in diameter after 10 days at $25^{\circ} \mathrm{C}$. Pale, salmon-colored sporodochia produced in culture lacked setae (Salgado-Salazar et al. 2019), whereas setae surrounding sporodochia were observed on infected pachysandra leaves (Fig. 5H). With the aid of a scanning electron microscope, we were also able to observe a previously unreported sporodochia-forming pattern of $C$. pachysandricola on naturally infected pachysandra, which was distinct from that of Pseudonectria spp. on boxwood. Namely, we observed that hyphae of Pseudonectria spp. first exited the stomata, and then sporodochia began to form on the surface of plant tissues (Fig. 5B and F). In contrast, $C$. pachysandricola formed spore-bearing conidiophores within stomata. The conidiophores of $C$. pachysandricola then erupted through stomata to develop into larger mature sporodochia (Fig. $5 \mathrm{H}$ ) (C. Salgado-Salazar, personal communication). This finding is supported by a closer observation of diagnostic plant samples, as the sporodochia of $C$. pachysandricola are usually restricted to the sites of stomata, and limited mycelia are seen on the surface of plant tissues (Fig. 3G). Whether the sporodochia-forming pattern is consistent across isolates of each species warrants further investigation.

On plant tissue but not in culture, setose perithecia of C. pachysandricola develop from old sporodochia or on stromatic tissue erupting from plant tissue (Dodge 1944b), with one or more perithecia developing from the stroma. Mature perithecia on pachysandra are orange-red to carmine-red (Fig. 3H), measuring 240 to $280 \times 200$ to $225 \mu \mathrm{m}$ (Dodge 1944 b) or 235 to $240 \times 180$ to $195 \mu \mathrm{m}$ (Rossman et al. 1993). Setae are yellowish, $135 \mu \mathrm{m}$ long, and interspersed with shorter hairs (Rossman et al. 1993). The asci are unitunicate, slightly clavate with a broad apex, measuring 46 to $58 \times 7$ to $8 \mu \mathrm{m}$ (Rossman et al. 1993 ) or 60 to $80 \times 7$ to $10 \mu \mathrm{m}$ (Dodge 1944b). Asci contain eight ascospores measuring 9.3 to $13.2 \times 3.1$ to $3.7 \mu \mathrm{m}$ (Rossman et al. 1993 ) or 10 to $15 \times 3$ to $4.5 \mu \mathrm{m}$ (Dodge 1944b). To date, perithecia of $C$. pachysandricola have not been observed on sarcococca.
Molecular Methods for Pathogen Identification and Detection

Identification of fungi causing Volutella blight using molecular tools relies on sequencing of one or more DNA markers, such as the rDNA internal transcribed spacer region (ITS), the universal barcode marker for fungi (Schoch et al. 2012), and the second largest subunit of the RNA polymerase I (rpb1) and II (rpb2) and larger subunit of the ATP citrate lyase (acll) for species discrimination in the Nectriaceae (Gräfenhan et al. 2011; Lombard et al. 2015). The DNA regions can be used for sequence analysis by finding regions of similarity between the query and reference sequences using nucleotide blast programs such as BLASTn provided by NCBI (Johnson et al. 2008). Phylogenetic reconstructions can be carried out to pinpoint the phylogenetic positions of the query sequences in relation to reference sequences of C. pachysandricola, $P$. buxi, and $P$. foliicola, which are publicly accessible in GenBank (Sayers et al. 2020). It is recommended that users rely on sequences obtained from types and/or phylogenetically and morphologically authenticated isolates for sequence comparison and phylogenetic analysis, such as those summarized in their Table 1 by Salgado-Salazar et al. (2019).

C. pachysandricola can be readily identified based on the ITS sequence because it shares less than $97 \%$ similarity with the most closely related species, C. rusci (Lombard et al. 2015). To discriminate between the morphologically similar $P$. buxi and $P$. foliicola, two species that also share more than $98.7 \%$ similarity in the ITS sequence, alternative DNA markers such as acll, rpbl, or $r p b 2$ can be used, either alone or in combination (Gräfenhan et al. 2011; Lombard et al. 2015; Salgado-Salazar et al. 2019).

With the advent of whole-genome sequencing, genomes of many boxwood-infecting fungi, including $C$. pachysandricola, $P$. buxi, and $P$. foliicola (Castroagudín et al. 2021; Rivera et al. 2018), have been sequenced. Whole-genome sequences of $C$. pachysandricola, $P$. buxi, and $P$. foliicola have the potential to aid the diagnosis of Volutella blight (Malapi-Wight et al. 2016b). Furthermore, although rapid diagnostic assays for Volutella blight are currently unavailable, a genomics approach can be used to identify informative DNA markers for rapid detection and subsequently facilitate the development of these assays, such as loop-mediated isothermal amplification (Malapi-Wight et al. 2016a).

\section{Pathogen Storage}

Active cultures of C. pachysandricola, P. buxi, and P. foliicola are usually maintained in PDA (Bezerra 1963; Gräfenhan et al. 2011; Rivera et al. 2018; Rossman et al. 1993; Shi and Hsiang 2014a, b). Other media types for these, or related species, include corn meal agar $+2 \%$ glucose, MEA (Rossman et al. 1993), and oatmeal agar (Bezerra 1963). For short-term storage, isolates without contamination can be maintained for 1 to 2 years at $4{ }^{\circ} \mathrm{C}$ in PDA in Petri dishes or glass slants sealed with Parafilm (Nakasone et al. 2004). Routine subculturing at least once a year should take place to maintain pure, live isolates (Nakasone et al. 2004). However, it is important to note that routine subculturing in a metabolically active state may result in phenotypic and genetic changes, including changes in virulence of fungal species (Crous 2002). Utilizing a combination of the long- and short-term storage methods can preserve the integrity of the collection, reducing the likelihood of these changes.

Several options exist for long-term storage of $C$. pachysandricola, $P$. buxi, and $P$. foliicola, including preservation with sterile mineral oil (Johnson and Martin 1992; Nakasone et al. 2004; Smith and Onions 1983; Stebbins and Robbins 1949), immersion in sterile 
water (Johnson and Martin 1992; Nakasone et al. 2004), and immersion in sterile glycerol (Nakasone et al. 2004). Mineral oil overlay of slant cultures is a traditional technique for preserving fungal isolates that is both economical and efficient, yielding several years of viability (Nakasone et al. 2004; Smith and Onions 1983). To preserve isolates using the mineral oil overlay technique, colonies of pure isolates grown on PDA slants are fully covered $1 \mathrm{~cm}$ above the top of the slant with twice-sterilized $\left(121^{\circ} \mathrm{C}\right.$ for 15 min) high-quality mineral oil (Smith and Onions 1983; Stebbins and Robbins 1949). Smith and Onions (1983) revived a culture of Pseudonectria sp. stored with this technique 32 years after preparation. Sterile water storage is a low-cost and effective method for preserving filamentous fungi for years (Johnson and Martin 1992; Nakasone et al. 2004). To apply this method, fungal isolates are grown on PDA for 7 to 10 days at $25^{\circ} \mathrm{C}$. Five to 10 plugs $\left(5 \mathrm{~mm}^{3}\right)$ are excised from the leading edge with a cork borer or scalpel and submerged in sterile water in a glass vial with screw-cap lid or a polypropylene microcentrifuge tube sealed with Parafilm. Isolates in sterile water can be stored at room temperature $\left(\sim 22^{\circ} \mathrm{C}\right)$ or at $4^{\circ} \mathrm{C}$ for several years. It is important to note that the effectiveness of sterile water is yet to be determined for storing $C$. pachysandricola, $P$. buxi, and $P$. foliicola, despite the fact that this method has been successful for other fungal species including Pseudonectria (Babu et al. 2015; Johnson and Martin 1992). Lastly, isolates of $C$. pachysandricola, $P$. buxi, and P. foliicola can be maintained in long-term storage in a metabolically inactive state at -20 or $-80^{\circ} \mathrm{C}$ in 10 to $15 \%$ sterile glycerol solution by immersing five to 10 plugs $\left(5 \mathrm{~mm}^{3}\right)$ excised from the leading edge of an active colony grown in PDA (Abd-Elsalam et al. 2010; Nakasone et al. 2004). This method has reliably worked for other pathogenic fungi and resulted in multiple years of viability with limited phenotypic changes (Abd-Elsalam et al. 2010).

Although other methods of storage may also work for C. pachysandricola, $P$. buxi, and $P$. foliicola, the discussed methods are simple and cost effective and do not require specialized equipment to preserve cultures. In general, it is our practice and recommendation to store cultures of $C$. pachysandricola, $P$. buxi, and $P$. foliicola in duplicate using multiple methods to ensure long-term viability and to safeguard against losses due to unexpected equipment failures or other issues.

\section{Pathogenicity Tests}

Pathogenicity of C. pachysandricola, $P$. buxi, and P. foliicola has been determined using detached leaves (Salgado-Salazar et al. 2019; Shi and Hsiang 2014a), potted plants (Garibaldi et al. 2016; Shi and Hsiang 2014a, b; Wang et al. 2017), or whole plants in the field (Spetik et al. 2020), with some variations in the inoculation process and incubation duration. It is common to create wounds on detached leaves during pathogenicity trials. This can be done with light scratches using sterile dissecting needles on the adaxial surfaces of leaves (Shi and Hsiang 2014a) or at either side of the leaf midrib (Salgado-Salazar et al. 2019). When stems and leaves of whole plants are inoculated, they can be wounded with a sterile 5-mm cork borer (Spetik et al. 2019). The number of wounded leaves can vary from three to 10 per plant (Garibaldi et al. 2016; Shi and Hsiang 2014a).

Wounded leaves are inoculated by spraying a conidial suspension that consists of $1 \times 10^{5}, 10^{6}$, or $10^{8}$ conidia/ml until runoff (Salgado-Salazar et al. 2019; Shi and Hsiang 2014a). Conidial suspensions are prepared by rinsing 7- to 21-day-old PDA cultures of $C$. pachysandricola, $P$. buxi, or $P$. foliicola with sterile distilled water. Control plants are sprayed with sterile water. For whole plants, a 5-mm mycelial plug taken from a 10-day-old PDA culture is placed onto each wound and secured with Parafilm or aluminum foil (Spetik et al. 2020).

Age of boxwood plants used in pathogenicity tests for $P$. buxi and $P$. foliicola can vary from 2- to 3-month-old rooted cuttings (Salgado-Salazar et al. 2019; Shi and Hsiang 2014b) to 2- to 3-year-old potted plants (Garibaldi et al. 2016; Shi and Hsiang 2014a; Spetik et al. 2019, 2020; Wang et al. 2017). The number of replications has also varied with the inoculation method. Each trial using whole plants typically includes three to eight inoculated replications plus at least one noninoculated control plant (Garibaldi et al. 2016; Shi and Hsiang 2014a; Spetik et al. 2019, 2020; Wang et al. 2017). For inoculating detached leaves, at least 10 replications are recommended to be used in each trial (Salgado-Salazar et al. 2019).

After inoculation, potted plants are covered with plastic bags (Garibaldi et al. 2016; Shi and Hsiang 2014a, b), whereas detached leaves are placed in closed moist chambers, at 20 to $25^{\circ} \mathrm{C}$ with a $14-\mathrm{h}$ photoperiod for approximately 3 days to facilitate infection (SalgadoSalazar et al. 2019). Lesions with sporodochia on wounded leaves are usually observed 3 days after inoculation, followed by yellowing and browning of tissues (Bai et al. 2012; Garibaldi et al. 2016; Shi and Hsiang 2014a, b), whereas the development of lesions under the bark of whole plants in the field can take up to 2 to 3 months (Spetik et al. 2019, 2020).

\section{Acknowledgments}

We are grateful to Dr. Gary R. Bauchan for producing the SEM images provided in this paper. We thank Dr. Raghuwinder Singh at Louisiana State University for commenting on the comparison chart in Figure 2, and Lorraine Graney, Meg McConnell, Vincent Simeone, and Chad Vrany for sharing images. This diagnostic guide is dedicated to the memory of the late Gary R. Bauchan, for his invaluable contribution to the production of high-quality micrographs that have greatly enhanced our understanding of plant pathogens.

\section{Literature Cited}

Abd-Elsalam, K. A., Yassin, M. A., Moslem, M. A., Bahkali, A. H., de Wit, P., McKenzie, E. H. C., Stephenson, S. L., Cai, L., and Hyde, K. D. 2010. Culture collections, the new herbaria for fungal pathogens. Fungal Divers. 45:21-32.

Akıllı Şimşek, S., Katircioglu, Y. Z., Cakar, D., Rigling, D., and Maden, S. 2019. Impact of fungal diseases on common box (Buxus sempervirens L.) vegetation in Turkey. Eur. J. Plant Pathol. 153:1203-1220.

Alfieri, S. A., Langdon, K. R., Wehlburg, C., and Kimbrough, J. W. 1984. Index of Plant Diseases in Florida (Revised). Florida Department of Agriculture and Consumer Services, Division of Plant Industry, Gainesville, FL.

Andrade, C. C. L., Duarte, V., Moreira, S. I., Dalbosco, M., Zanin, J. G., Telo, P. S., and Alves, E. 2017. First report of Pseudonectria buxi causing leaf and stem blight on boxwood in Santa Catarina, Brazil. Plant Dis. 101:13261327.

Anonymous. 1960. Index of Plant Diseases in the United States. Agricultural Handbook no. 165. USDA, Washington, DC

Babu, A. G., Kim, S. W., Yadav, D. R., Adhikari, M., Kim, C., Lee, H. B., and Lee, Y. S. 2015. A new record of Volutella ciliata isolated from crop field soil in Korea. Mycobiology 43:71-74.

Bai, Q., Xie, Y., Dong, R., Gao, J., and Li, Y. 2012. First report of Volutella blight on Pachysandra caused by Volutella pachysandricola in China. Plant Dis. 96:584-585.

Baysal-Gurel, F., Bika, R., Avin, F. A., Jennings, C., and Simmons, F. 2021. Occurrence of Volutella blight caused by Pseudonectria foliicola on boxwood in Tennessee. Plant Dis. https://doi.org/10.1094/PDIS-01-210109-PDN.

Bezerra, J. L. 1963. Studies on Pseudonectria rousseliana. Acta Bot. Neerl. 12: 58-63.

Bobev, S. 2009. Reference Guide for the Diseases of Cultivated Plants. In Russian. Makros Publishers, Plovdiv, Bulgaria. 
Cannon, P. F., Hawksworth, D. L., and Sherwood-Pike, M. A. 1985. The British Ascomycotina: An Annotated Checklist. Commonwealth Mycological Institute, Kew, U.K.

Castroagudín, V. L., Shishkoff, N., Stanley, O., Whitesell, R., Olson, T., and Crouch, J. A. 2021. First report: Coinfection of Sarcococca hookeriana (sweetbox) by Coccinonectria pachysandricola and Calonectria pseudonaviculata causes a foliar disease of sweetbox in Pennsylvania. Plant Dis. https://doi.org/10.1094/ PDIS-06-20-1198-PDN.

Castroagudín, V. L., Yang, X., Daughtrey, M. L., Luster, D. G., Pscheidt, J. W., Weiland, J. E., and Crouch, J. A. 2020. Boxwood blight disease: A diagnostic guide. Plant Health Prog. 21:291-300.

Collado, J., Platas, G., Gonzalez, I., and Pelaez, F. 1999. Geographical and seasonal influences on the distribution of fungal endophytes in Quercus ilex. New Phytol. 144:525-532.

Crous, P. W. 2002. Taxonomy and Pathology of Cylindrocladium (Calonectria) and Allied Genera. APS Press, St. Paul, MN.

de Sousa Dias, M. R., Lucas, M. T., and Lopes, M. C. 1987. Fungi Lusitaniae XXX. Agron. Lusit. 42:179-188.

Dodge, B. O. 1944a. Boxwood blights and Hyponectria buxi. Mycologia 36: 215-222.

Dodge, B. O. 1944b. A new Pseudonectria on Pachysandra. Mycologia 36: 532-537.

Dodge, B. O. 1944c. Volutella buxi and Verticillium buxi. Mycologia 36: 416-425

Douglas, S. M. 2008. Volutella blight of Pachysandra. PP053 (11/03R). Connecticut Agricultural Experiment Station. https://portal.ct.gov/CAES/ Fact-Sheets/Plant-Pathology/Volutella-Blight-of-Pachysandra.

Eriksson, O. E. 1992. The Non-lichenized Pyrenomycetes of Sweden. SBTforlaget, Lund, Sweden.

Erwin, D. C., and Ribeiro, O. K. 1996. Phytophthora Diseases Worldwide. APS Press, St. Paul, MN.

Farr, D. F., and Rossman, A. Y. 2020. Fungal Databases, U.S. National Fungus Collections, Agricultural Research Service, United States Department of Agriculture. Retrieved October 27, 2020, from https://nt.ars-grin.gov/ fungaldatabases/.

French, A. M. 1989. California Plant Disease Host Index. California Department of Food and Agriculture, Sacramento, CA

Garibaldi, A., Bertetti, D., Ortu, G., and Gullino, M. L. 2016. First report of Volutella blight caused by Pseudonectria buxi on Japanese boxwood (Buxus microphylla) in Italy. Plant Dis. 100:1499-1500.

Gräfenhan, T., Schroers, H. J., Nirenberg, H. I., and Seifert, K. A. 2011. An overview of the taxonomy, phylogeny, and typification of nectriaceous fungi in Cosmospora, Acremonium, Fusarium, Stilbella, and Volutella. Stud. Mycol. 68:79-113.

Grand, L. F. 1985. North Carolina Plant Disease Index. North Carolina Agricultural Research Service, Raleigh, NC.

Han, K. S., Park, J. H., Cho, S. E., and Shin, H. D. 2012. First report of leaf blight and stem canker of Pachysandra terminalis caused by Pseudonectria pachysandricola in Korea. Plant Dis. 96:287.

Hansen, M. A. 2009. Major Diseases of Boxwood. Publication 450-614. Virginia Cooperative Extension, Blacksburg, VA.

Hudler, G. W., Neal, B. G., and Banik, M. T. 1990. Effects of growing conditions on wound repair and disease resistance in Pachysandra terminalis. Phytopathology 80:272-277.

Hutchinson, W. G. 1929. An undescribed species of Macrophoma and of Volutella occurring on Pachysandra terminalis. Mycologia 21:131-142.

Johnson, G. C., and Martin, A. K. 1992. Survival of wood-inhabiting fungi stored for 10 years in water and under oil. Can. J. Microbiol. 38:861-864.

Johnson, M., Zaretskaya, I., Raytselis, Y., Merezhuk, Y., McGinnis, S., and Madden, T. L. 2008. NCBI BLAST: A better web interface. Nucleic Acids Res. 36:W5-W9.

Kobayashi, T. 2007. Index of Fungi Inhabiting Woody Plants in Japan: Host, Distribution and Literature. Zenkoku Noson Kyoiku Kyokai Publishing, Tokyo, Japan

Lambe, R. C., and Wills, W. H. 1975. Decline of English boxwood in Virginia. Plant Dis. Rep. 59:105-108.

Lombard, L., van der Merwe, N. A., Groenewald, J. Z., and Crous, P. W. 2015. Generic concepts in Nectriaceae. Stud. Mycol. 80:189-245.

Malapi-Wight, M., Demers, J. E., Veltri, D., Marra, R. E., and Crouch, J. A. 2016a. LAMP detection assays for boxwood blight pathogens: A comparative genomics approach. Sci. Rep. 6:26140.

Malapi-Wight, M., Salgado-Salazar, C., Demers, J. E., Clement, D. L., Rane, K. K., and Crouch, J. A. 2016b. Sarcococca blight: Use of whole-genome sequencing for fungal plant disease diagnosis. Plant Dis. 100:1093-1100.

Malinoski, M. K., Clement, D. L., and Bosmans, R. 2020. Boxwood: Diagnose, manage and prevent common problems. University of Maryland Extension,
Home and Garden Information Center. https://extension.umd.edu/resource/ boxwood-diagnose-manage-and-prevent-common-problems.

Mulenko, W., Majewski, T., and Ruszkiewicz-Michalska, M. 2008. A Preliminary Checklist of Micromycetes in Poland. W. Szafer Institute of Botany, Polish Academy of Sciences, Kraków, Poland.

Munk, A. 1957. Danish Pyrenomycetes: A Preliminary Flora. Dansk Botanisk Arkiv, no. 17. Munksgaard, Copenhagen, Denmark.

Nakasone, K. K., Peterson, S. W., and Jong, S. C. 2004. Preservation and distribution of fungal cultures. Pages 37-47 in: Biodiversity of Fungi: Inventory and Monitoring Methods. M. S. Foster, G. F. Bills, and G. M. Mueller, eds. Elsevier Academic, Cambridge, MA.

Pantidou, M. E. 1973. Fungus-Host Index for Greece. Benaki Phytopathological Institute, Kiphissia, Athens, Greece.

Pirone, P. P. 1942. Stem and stolon canker of pachysandra: Nursery and disease notes. N.J. Agric. Experiment Stn. 14:40-43.

Reeser, P. W., Sutton, W., Hansen, E. M., Goheen, E. M., Fieland, V. J., and Grünwald, N. J. 2015. First report of Phytophthora occultans causing root and collar rot on ceanothus, boxwood, rhododendron, and other hosts in horticultural nurseries in Oregon, USA. Plant Dis. 99:12821283.

Rivera, Y., Salgado-Salazar, C., Veltri, D., Malapi-Wight, M., and Crouch, J. A. 2018. Genome analysis of the ubiquitous boxwood pathogen Pseudonectria foliicola. PeerJ 6:e5401.

Rogerson, C. T. 1953. Kansas Mycological Notes: 1951. Trans. Kans. Acad. Sci. 56:53-57.

Rogerson, C. T. 1956. Kansas Mycological Notes: 1953-1954. Trans. Kans. Acad. Sci. 59:39-48.

Rossman, A. Y., Samuels, G. J., and Lowen, R. 1993. Leuconectria clusiae gen. nov. and its anamorph Gliocephalotrichium bulbilium with notes on Pseudonectria. Mycologia 85:685-704.

Safránková, I. 2005. First report of Volutella pachysandricola on Pachysandra terminalis in the Czech Republic. Plant Pathol. 54:808

Safránková, I. 2007. Volutella leaf blight and stem canker on Japanese pachysandra in the Czech Republic. Plant Prot. Sci. 43:10-12.

Salgado-Salazar, C., Shiskoff, N., LeBlanc, N., Ismaiel, A. A., Collins, M., Cubeta, M. A., and Crouch, J. A. 2019. Coccinonectria pachysandricola, causal agent of a new foliar blight disease of Sarcococca hookeriana. Plant Dis. 103:1337-1346.

Samuels, G. J. 1977. Nectria consors and its Volutella conidial state. Mycologia 69:255-262.

Sayers, E. W., Cavanaugh, M., Clark, K., Ostell, J., Pruitt, K. D., and KarschMizrachi, I. 2020. GenBank. Nucleic Acids Res. 48:D84-D86.

Schoch, C. L., Seifert, K. A., Huhndorf, S., Robert, V., Spouge, J. L., Levesque, C. A., Chen, W., Dentinger, B., Dieguez-Uribeondo, J., Divakar, P. K., Douglas, B., Duenas, M., Duong, T. A., Eberhardt, U., Edwards, J. E., Elshahed, M. S., Fliegerova, K., Furtado, M., Garcia, M. A., Ge, Z. W., Griffith, G. W., Griffiths, K., Groenewald, J. Z., Groenewald, M., Grube, M., Gryzenhout, M., Guo, L. D., Hagen, F., Hambleton, S., Hamelin, R. C., Hansen, K., Harrold, P., Heller, G., Herrera, G., Hirayama, K., Hirooka, Y., Ho, H. M., Hoffmann, K., Hofstetter, V., Hognabba, F., Hollingsworth, P. M., Hong, S. B., Hosaka, K., Houbraken, J., Hughes, K., Huhtinen, S., Hyde, K. D., James, T., Johnson, E. M., Johnson, J. E., Johnston, P. R., Jones, E. B., Kelly, L. J., Kirk, P. M., Knapp, D. G., Koljalg, U., Kovacs, G. M., Kurtzman, C. P., Landvik, S., Leavitt, S. D., Liggenstoffer, A. S., Liimatainen, K., Lombard, L., Luangsa-Ard, J. J., Lumbsch, H. T., Maganti, H., Maharachchikumbura, S. S., Martin, M. P., May, T. W., McTaggart, A. R., Methven, A. S., Meyer, W., Moncalvo, J. M., Mongkolsamrit, S., Nagy, L. G., Nilsson, R. H., Niskanen, T., Nyilasi, I., Okada, G., Okane, I., Olariaga, I., Otte, J., Papp, T., Park, D., Petkovits, T., Pino-Bodas, R., Quaedvlieg, W., Raja, H. A., Redecker, D., Rintoul, T. L., Ruibal, C., Sarmiento-Ramirez, J. M., Schmitt, I., Schussler, A., Shearer, C., Somtome, K., Stefani, F. O. P., Stenroos, S., Stielow, B., Stockinger, H., Suetrong, S., Suh, S. O., Sung, G. H., Suzuki, M., Tanaka, K., Tedersoo, L., Telleria, M. T., Tretter, E., Untereiner, W. A., Urbina, H., Vagvolgyi, C., Vialle, A., Vu, T. D., Walther, G., Wang, Q. M., Wang, Y., Weir, B. S., Weiss, M., White, M. M., Xu, J., Yahr, R., Yang, Z. L., Yurkov, A., Zamora, J. C., Zhasng, N., Zhuang, W. Y., and Schindel, D. 2012. Nuclear ribosomal internal transcribed spacer (ITS) region as a universal DNA barcode marker for Fungi. Proc. Natl. Acad. Sci. U.S.A. 109:6241-6246.

Shi, F., and Hsiang, T. 2014a. First report of Pseudonectria buxi causing Volutella blight on boxwood (Buxus sp.) in Beijing, China. Plant Dis. 98: 1282-1283.

Shi, F., and Hsiang, T. 2014b. Pseudonectria buxi causing leaf and stem blight on Buxus in Canada. Eur. J. Plant Pathol. 138:763-773.

Simonyan, S. A. 1981. Mycoflora of Botanical Gardens and Arboreta in Armenia. Russian. Hayka, Armenian SSR USSR. 
Sinclair, W. A., Lyon, H. H., and Johnson, W. T. 1987. Diseases of Trees and Shrubs. Cornell University Press, Ithaca, NY.

Singh, R., and Doyle, V. P. 2017. Boxwood dieback caused by Colletotrichum theobromicola: A diagnostic guide. Plant Health Prog. 18:174-180.

Singh, R., Graney, L., and Williamson, M. 2015. First report of boxwood dieback caused by Colletotrichum theobromicola in the United States. Plant Dis. 99:1274.

Smith, D., and Onions, A. H. S. 1983. A comparison of some preservation techniques for fungi. Trans. Br. Mycol. Soc. 81:535-540.

Spetik, M., Berraf-Tebbal, A., Cechova, J., and Eichmeier, A. 2020. Occurrence of Pseudonectria foliicola causing Volutella blight on boxwood in Czech Republic. Plant Dis. 104:1547-1548.
Spetik, M., Berraf-Tebbal, A., Penazova, E., Pecenka, J., Maier, M., and Eichmeier, A. 2019. First report of Pseudonectria buxi causing Volutella blight on boxwood in Czech Republic. Plant Dis. 103:1790-1791.

Stebbins, M. E., and Robbins, W. J. 1949. Mineral oil and preservation of fungous cultures. Mycologia 41:632-636.

Unamuno, L. M. 1941. Enumeración y distribución geográfica de los Ascomicetos de la península ibérica y de las islas Baleares. Aguirre, Madrid, Spain.

Wang, X., Li, Y. X., Dong, H. X., Jia, X. Z., and Zhang, X. Y. 2017. First report of Volutella buxi causing Volutella blight on Buxus bodinieri in Central Plains China. Plant Dis. 101:1325-1326.

White, R. P. 1931. Disease of boxwood. N.J. Agric. Experiment Stn. Circ. 230: 230-244. 